\title{
Dentt[des $\mathbb{R e}[$ ebutd
}

furr

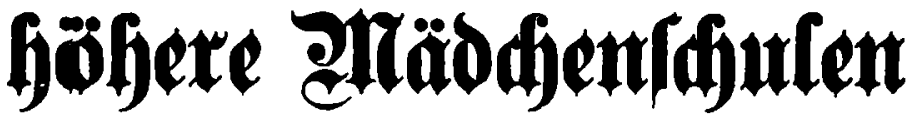

herausgegeben

von

dax seffel.

\section{vicrter Ecil. \\ Erste Fbteilung, Gedide.}

sedfte, moeranderte Fuflage.

boun 1905.

Q. Marcus und E. Webers Berlag. 
